\title{
Problems and Solutions in the Genetic Analysis of Late-Onset Alzheimer's Disease
}

\author{
John Hardy Amanda Myers Fabienne Wavrant-De Vrieze \\ Laboratory of Neurogenetics, National Institute on Aging, National Institutes of Health, Bethesda, Md., USA
}

\section{Key Words}

Alzheimer's disease · Apolipoprotein E · Amyloid protein precursor · Presenilin

\begin{abstract}
The identification of the apolipoprotein $\mathrm{E}$ gene as a risk factor for late-onset Alzheimer's disease was a spectacularly successful application of genetic analysis to a complex trait, and it led to the hope and expectation that other risk loci for the disease would soon be forthcoming. Twelve years later, despite a huge amount of work, no other loci have been identified. In this article, we discuss the complexity of the problem and the pitfalls in the analytical methods that have been used and how we are approaching this problem.
\end{abstract}

Copyright @ 2004 S. Karger AG, Basel

Mutations in amyloid protein precursors and the presenilins cause autosomal dominant, early-onset Alzheimer's disease because they alter amyloid protein precursor processing such that $A \beta$ deposition is a more likely event [1-5]. These findings have clearly shown that amyloid processing is the central initiating event in Alzheimer pathogenesis. However, coding mutations in these genes do not contribute to the risk of the far more prevalent lateonset disease. Apolipoprotein $\mathrm{E}$ is the only locus known to contribute to the risk of developing the late-onset form of disease with the $\mathrm{E} 4$ allele increasing risk of disease and the E2 allele decreasing risk of disease [6, 7]. The precise mechanism of apolipoprotein E's pathogenesis is not clear but clearly relates to the process of $A \beta$ deposition [8]. Given that the known role of apolipoprotein $\mathrm{E}$ in the periphery is in cholesterol metabolism and the probable influence of cholesterol on Alzheimer pathogenesis [9, 10], perhaps the most parsimonious expectation would be that apolipoprotein E's effect is mediated through modulation of cholesterol homeostasis in the brain.

While it is clear that apolipoprotein $\mathrm{E}$ is a major risk factor for Alzheimer's disease, epidemiological studies estimate that $42-68 \%$ of late-onset Alzheimer's disease cases do not have an apolipoprotein E4 allele, indicating that additional genetic and environmental factors are involved in this form of the disease [11-14]. Genetic epidemiological analysis has suggested that there may be 4-7 other genes that influence Alzheimer risk [15].

Thus, for the last $\sim 10$ years, there has been a concerted effort to find the other genes. We apparently have had all the advantages: large sample series, many groups working on the problem, a defined pathway to pathogenesis and a success story, apolipoprotein E, to learn from

\section{KARGER \\ Fax +4161306 1234 \\ E-Mail karger@karger.ch \\ www.karger.com \\ (C) 2004 S. Karger AG, Basel \\ $1660-2854 / 04 / 0015-0213 \$ 21.00 / 0$ \\ Accessible online at: \\ www. karger.com/ndd}

John Hardy, PhD

Laboratory of Neurogenetics, National Institute on Aging

National Institutes of Health, Building 35, Room 1A1015, MSC3707

Convent Drive, Bethesda, MD 20892-3707 (USA)

Tel. +1 301480 6076, Fax +1 301480 0335, E-Mail hardyj@mail.nih.gov 
and yet, there has been little progress. There is much heat but little light. In this brief review we discuss the potential reasons for our continuing failure to find the expected other risk loci for Alzheimer's disease.

There are essentially two methods that have been used to try and find other genes for Alzheimer's disease: affected family member linkage methods and case-control studies. In the former, genetic loci are tested for cosegregation within small families, often sibpairs, for evidence of allele sharing at different chromosomal positions. In the latter, genetic variability in candidate genes is tested with association with disease. Both of these approaches have strengths and weaknesses.

\section{Linkage-Based Methods}

The strength of linkage methods is that they are not hypothesis driven and thus can yield unexpected findings. However, their weakness is that the collection of adequate sample series is very difficult and indeed, the major weakness of this approach has been that very few samples (compared with the amount needed) have been collected. In fact, there are two large publicly available series which largely consist of affected sibpairs and their unaffected sibs (NIA and MIMH) [16-18] and, in addition, there area few smaller private series including that analyzed by the Duke group [19], that analyzed by the Cardiff/NIA/ Washington University Consortium [18], and that collected by the Columbia group [20]. This overlap of samples has led to the unfortunate circumstance that none of the published analyses are genuinely independent replications or refutations of each other since there has always been a large degree of overlap in the samples analyzed. Added to this dilemma are the additional problems that all the analyses are underpowered and that the approach, of its nature, gives very poor genetic resolution [21]. Part of the reason that the approach is underpowered is that there is a degree of multiple testing: analyses are often split by apolipoprotein E genotype and genetic linkage to age of onset has been added to the list of possible outcomes of the same dataset. Recently, a new method, which adds to the problems of multiple testing, has been devised: coupling the data with linkage data for Parkinson's disease [22]. A final and subtle method to add to the problems of multiple testing is to report analyses of single chromosomes under different conditions in comparison with the analysis of the whole genome. This allows the investigator to inadvertently tune their data for lod score maximization. Given the complexity of the situation, sig- nificance levels can only be assessed in the context of a whole genome analysis. As an example, the report of chromosome 10 data is very different when reported singly than when it was reported in the context of the whole genome [23, 24]. While it is certainly justifiable to add these more complex analyses as subsidiary outcomes to generate new hypotheses, since there are no datasets in which these new hypotheses can be tested, they merely add to the confusion as they, therefore, are assumed to be primary outcome measures. Finally, there is the issue of the 'winner's curse'. In all studies looking for linkage, there is a tendency for the first report of linkage to overstate the statistical significance of the effect. This can be a difficult problem to understand, but let us suppose that two studies performed a genome screen with samples from the same population of Alzheimer sibpairs. Locus $L$ has a moderate effect on disease risk, which, based on the strength of its association, should generate a mean lod score of 2; however, study 1 gets a lod score of 1 at $L$, and does not report it, but study 2 gets a lod score of 3 and does. This example illustrates that initial studies of linkage are always likely to overestimate the strength of any linkage signal and that the strength of any signal can only truly be estimated by subsequent studies. Since, as we have noted, there is a paucity of independent datasets, this latter condition has not yet been met for any locus. It is noteworthy, however, that the linkage screens for lateonset Alzheimer's disease have yielded a relatively modest signal on chromosome 19 at the apolipoprotein E locus. Furthermore, it is clear that apolipoprotein E modifies risk of Alzheimer's disease by modulating the age at onset, and yet it did not show up in screens designed to identify loci with this characteristic [22]. The comparative weakness of the apolipoprotein E signal in linkage screens for late-onset disease, and its failure to be observed in screens designed to pick up age at onset-modifying genes is an illustration of the inherent lack of power of these screens, and also of the dangers inherent in interpreting linkage data from these studies, since it is quite possible that we are interpreting random fluctuations in linkage signals as true peaks. The application of more statistical analyses adds to this problem and it can only be solved by truly independent replication. Unfortunately, it is far easier to continue to reanalyze data than to collect and genotype more samples. Clearly more and independent series of sibpair series as well as the collection of isolated populations with Alzheimer's disease such as Israeli Arabs [25] are needed to allow for genuine replications to be achieved. Publication bias adds to these difficult problems. This is dealt with in more detail below. 


\section{Association Studies}

Association studies are usually of the case-control design and often the controls are the spouses. Some studies prefer to use sib controls, which is less powerful, but has the advantage that population stratification is less of an issue. In many ways a case-control study is the perfect design; it provides the direct mathematical answer to the question 'does allele A occur more often in Alzheimer cases than in controls?'. However, there are serious problems with its use in practice, chief of which is the problem of multiple testing.

Multiple testing is a slippery fish. It behooves us to consider the potentials for multiple tests in simple, single polymorphism, association studies: do we report genotype associations or allelic associations? Do we divide by apolipoprotein E genotype? Do we divide analyses by gender? Do we separate by age of onset? If we separate by age at onset, how did we choose that age? When we move to haplotype association studies, the problems are compounded exponentially: which polymorphisms do we report, and which combinations do we choose? If we assess 5 polymorphisms from a locus but report 3 polymorphism haplotypes, clearly we have potentially indulged in an enormous amount of hidden testing. Thus, all of these questions above impact on the multiple testing problem, but in ways that are difficult to quantitate. More seriously, the reader of any report cannot know what tests were considered but not reported. Indeed, it is difficult for the author of the report to appreciate how much he or she looked at the data before deciding which analyses to report. This is currently the most serious problem confronting the analysis of genetic data: it is confounded by publication bias, and presently can only be overcome by independent replication.

Publication bias is a serious problem amplifying the issues related to multiple testing. If 20 groups test a locus for association with disease, and 19 find no association, and one gets a $\mathrm{p}$ value of 0.05 , the 'successful' group is far more likely to be able to publish than the 19 others: high impact journals want to be sent papers reporting new Alzheimer genes, but even low impact journals are chary of taking papers which refute them. The higher the impact factor of the journal, the more irresponsible has its attitude been to this problem, and they, and investigators and their institutions, have compounded this problem with irresponsible press releases. 'New Alzheimer Gene' is a good headline: 'New Alzheimer Gene Refuted' is not. The entry into the field of the biotech industry has compounded this problem since it is difficult for them to admit errors that will affect their share price.

Finally, independent replication is traditionally and appropriately seen as the panacea for all the problems, both with the linkage approaches and with the association studies. Unfortunately, this approach is currently not feasible with the linkage studies since there are no truly independent datasets available. However, it should be feasible with association studies. Unfortunately, this has also proved difficult in practice since 'replication' has also proven to be a slippery fish. If an allelic association is reported, for example, between a 3-locus haplotype and Alzheimer's disease, does a subsequent study reporting an association between a different 3-locus diplotype and disease seen only in apolipoprotein E4 carriers constitute replication? And then, what of a third study, reporting that the original 3-locus haplotype does not affect disease occurrence, but does influence age at onset of disease? Does this circumstance reflect the likelihood that there is indeed something happening at the locus and that different populations have slightly different predispositions, or merely the fact that researchers need to publish papers reporting progress and will continue to carry out statistical tests until they have something to report? The problem is that, in these circumstances, the scientific literature is becoming as complex as the biological problem.

\section{Is There a Way Forward?}

Clearly, after 10 years of failing to find other Alzheimer genes, it is time to assess what needs to be done: first, there has to be an acknowledgement that, while it seems unlikely that there are no other genes involved in Alzheimer's disease the estimate of 4-7 other genes for disease is not certain because it is derived from the analysis of unrepresentative families and thus it is difficult to quantify ascertainment bias issues. Indeed the analysis largely neglects the possibility that shared environments may also contribute to familial clustering. Second, publications with press releases should be discouraged. Third, journals need to take responsibility for what they publish and be prepared always to accept some competent refutations of any reports they publish rather than riding on the eternal good news of positive reports and fourth, secondary analyses (based on age-at-onset analyses or secondary clinical characteristics) should be reported as such and as hypothesis generating reports rather than as definitive evidence for association. 
Table 1. ApoE allele frequencies in Alzheimer cases and controls and in Alzheimer sibpairs who share alleles on chromosome 19

\begin{tabular}{|c|c|c|c|}
\hline & $\mathrm{E} 4, \%$ & E3, \% & $\mathrm{E} 2, \%$ \\
\hline Affected sibs, all & 42 & 54 & 4 \\
\hline Unaffected sibs & 23 & 66 & 10 \\
\hline \multirow{3}{*}{$\begin{array}{l}\text { Affected sibs who share chromosome } 19 \\
\text { Affected sibs who do not share } \\
\text { chromosome } 19\end{array}$} & 47 & 51 & 2 \\
\hline & & & \\
\hline & 34 & 61 & 5 \\
\hline Cases & 32 & 64 & 4 \\
\hline Controls & 12 & 81 & 7 \\
\hline
\end{tabular}

Data adapted from Myers et al. [18], showing both the apolipoprotein E4 association in a case-control setting, but also that this association is more pronounced in those sibpairs which share chromosome 19 markers. Note also that sibpairs who do not share chromosome 19 markers have the same allele frequencies as a typical case-control series and that unaffected sibs of affected sibpairs have an increased E2 frequency consistent with this being a protective allele ( $\mathrm{n}>200$ in all cases). These data should, in general, be replicated by other risk factor alleles at other chromosomal locations.

On the positive side, the needs are clear. Larger and diverse publicly accessible sample series from both multiply affected families and from case-control series are required so that the linkage scans can be repeated and so that, when a group observes an apparent association, they can then replicate it in an independent sample. Partly through the DIADEM collaboration, we are now increas- ing the complete sibpair genome screen from $\sim 450$ sibpairs $[18,23]$ to $\sim 900$ sibpairs. In addition, we are developing a sibpair allele sharing resource making use of the fact that a risk factor allele should have a higher frequency in sibpairs which share the chromosome locus, enabling the development of another hurdle to prevent false positives. Thus, in our view, a true risk factor allele for Alzheimer's disease should have an increased allele frequency in a case-control series, but should have an even higher frequency in sibpairs who share that locus. This effect is illustrated in table 1. Use of the sibpairs in the way illustrated in table 1 allows another and independent test of association with disease: a risk allele should have highest frequencies in sibpairs who share the chromosomal region, intermediate frequencies in sibpairs who do not share the locus and in standard cases, and lowest frequency in controls. By making these sibpairs and the linkage data freely available, the potential to find risk alleles is open to all, but the hurdles for false positives are increased.

\section{Acknowledgments}

This work and collaborations to follow this workup were supported by the European Union under the programme 'Quality of Life and Management of Living Resources', Key Action 3 'The Cell Factory', Contract No. QLK3-CT-2001-02362 and through the Verum Foundation. Collaborations with Dr. Lars Lannfelt and Dr. Andreas Papassotiropoulos through this EU grant are gratefully acknowledged.

\section{References}

1 Goate AM, Chartier-Harlin MC, Mullan MC, Brown J, Crawford F, Fidani L, Giuffra L, Haynes A, Irving N, James L, Mant R, Newton $\mathrm{P}$, Rooke K, Roques P, Talbot C, PericakVance M, Roses A, Williamson R, Rossor MN, Owen M, Hardy J: Segregation of a missense mutation in the amyloid precursor protein gene with familial Alzheimer's disease. Nature 1991;349:704-706.

$>2$ Sherrington R, Rogaev EL, Liang Y, Rogaeva EA, Levesque G, Ikeda M, Chi H, Lin C, Li G, Holman K, Tsuda T, Mar L, Foncin JF, Brun AC, Montesi MP, Sorbi S, Rainero I, Pinessi L, Nee L, Chumakov I, Pollen D, Brookes A, Sanseau P, Polinsky RJ, Wasco W, Da Silva HAR, Haines JL, Pericak Vance M, Tanzi RE, Roses AD, Fraser PE, Rommens JM, St George Hyslop PH: Cloning of a gene bearing missense mutations in early-onset familial Alzheimer's disease. Nature 1995;375:754-760.
Levy-Lahad E, Wasco W, Poorkaj P, Romano DM, Oshima J, Pettingell WH, Yu CE, Jondro PD, Schmidt SD, Wang K, et al: Candidate gene for the chromosome 1 familial Alzheimer's disease locus. Science 1995;269:973977.

4 Rogaev EI, Sherrington R, Rogaeva EA, Levesque $\mathrm{G}$, Ikeda M, Liang Y, Chi H, Lin C, Holman K, Tsuda T, et al: Familial Alzheimer's disease in kindreds with missense mutations in a gene on chromosome 1 related to the Alzheimer's disease type 3 gene. Nature 1995;376: 775-778.

$\checkmark 5$ Hardy J: Amyloid, the presenilins and Alzheimer's disease. Trends Neurosci 1997;20: 154-159.

6 Corder EH, Saunders AM, Strittmatter WJ, Schmechel DE, Gaskell PC, Small GW, Roses AD, Haines JL, Pericak-Vance MA: Gene dose of apolipoprotein E type 4 allele and the risk of Alzheimer's disease in late onset families. Science 1993;13:921-923.
7 Chartier-Harlin MC, Parfitt M, Legrain S, Perez-Tur J, Brousseau T, Evans A, Berr C, Vidal $\mathrm{O}$, Roques P, Gourlet V, et al: Apolipoprotein E, epsilon 4 allele as a major risk factor for sporadic early and late-onset forms of Alzheimer's disease: Analysis of the 19q13.2 chromosomal region. Hum Mol Genet 1994;3:569-574.

$>8$ Bales KR, Verina T, Cummins DJ, Du Y, Dodel RC, et al: Apolipoprotein E is essential for amyloid deposition in the APP(V717F) transgenic mouse model of Alzheimer's disease. Proc Natl Acad Sci USA 1999;96:1523315238.

$>9$ Wolozin B, Kellman W, Ruosseau P, Celesia GG, Siegel G: Decreased prevalence of Alzheimer disease associated with 3-hydroxy-3methyglutaryl coenzyme A reductase inhibitors. Arch Neurol 2000;57:1439-1443. 
10 Refolo LM, Pappolla MA, LaFrancois J, Malester B, Schmidt SD, et al: A cholesterol-lowering drug reduces beta-amyloid pathology in a transgenic mouse model of Alzheimer's disease. Neurobiol Dis 2001;8:890-899.

11 Lucotte G, Visvikis S, Leininger-Muler B, David $F$, Berriche $S$, Reveilleau $S$, Couderc $R$, Babron MC, Aguillon D, Siest G: Association of apolipoprotein $\mathrm{E}$ allele epsilon 4 with lateonset sporadic Alzheimer's disease. Am J Med Genet 1994;54:286-288.

12 Henderson AS, Easteal S, Jorm AF, Mackinnon AJ, Korten AE, Christensen H, Croft L, Jacomb PA: Apolipoprotein E allele epsilon 4, dementia, and cognitive decline in a population sample. Lancet 1995;346:1387-1390.

13 Ritchie K, Kotzki PO, Touchon J, Cristol JP: Characteristics of Alzheimer's disease patients with and without ApoE4 allele. Lancet 1996; 348:960.

-14 Farrer LA, Cupples LA, Haines JL, Hyman B, Kukull WA, Mayeux R, Myers RH, PericakVance MA, Risch N, van Duijn CM: Effects of age, sex, and ethnicity on the association between apolipoprotein E genotype and Alzheimer disease. A meta-analysis. APOE and Alzheimer Disease Meta Analysis Consortium. Ann Neurol 1995;38:797-808.

15 Daw EW, Heath SC, Wijsman EM: Multipoin oligogenic analysis of age-at-onset data with applications to Alzheimer disease pedigrees. Am J Hum Genet 1999;64:839-851.

$\checkmark 16$ Blacker D, Haines JL, Rodes L, Terwedow H, Go RC, Harrell LE, Perry RT, Bassett SS, Chase G, Meyers D, Albert MS, Tanzi R: ApoE-4 and age at onset of Alzheimer's disease: The NIMH genetics initiative. Neurology 1997;48:139-147.
17 Kehoe P, Wavrant-De Vrieze F, Crook R, Wu WS, Holmans P, Fenton I, Spurlock G, Norton $\mathrm{N}$, Williams H, Williams N, Lovestone S, Pérez-Tur J, Hutton M, Chartier-Harlin MC, Shears S, Roehl K, Booth J, Van Voorst W, Ramic D, Williams J, Goate A, Hardy J, Owen MJ: A full genome scan for late onset Alzheimer's disease. Hum Mol Genet 1999;8:237245.

18 Myers A, Wavrant-De Vrieze F, Holmans P, Hamshere M, Crook R, Compton D, Marshall H, Meyer D, Shears S, Booth J, Ramic D, Knowles H, Morris JC, Williams N, Norton N, Abraham R, Kehoe P, Williams H, Rudrasingham V, Rice F, Giles P, Tunstall N, Jones L, Lovestone S, Williams J, Owen MJ, Hardy J, Goate A: Full genome screen for Alzheimer disease: Stage II analysis. Am J Med Genet 2002; 114:235-244.

19 Pericak-Vance MA, Grubber J, Bailey LR, Hedges D, West S, Santoro L, Kemmerer B, Hall JL, Saunders AM, Roses AD, Small GW, Scott WK, Conneally PM, Vance JM, Haines JL: Identification of novel genes in late-onset Alzheimer's disease. Exp Gerontol 2000;35: 1343-1352.

20 Romas SN, Santana V, Williamson J, Ciappa A, Lee JH, Rondon HZ, Estevez P, Lantigua R, Medrano M, Torres M, Stern Y, Tycko B, Mayeux R: Familial Alzheimer disease among Caribbean Hispanics: A reexamination of its association with APOE. Arch Neurol 2002;59: 87-91.

21 Chataway J, Feakes R, Coraddu F, Gray J, Dea J, Fraser M, Robertson N, Broadley S, Jaer M, Clayton D, Goodfellow P, Sawcer S, Compston A: The genetics of MS: The United Kingdom sibpair analysis: Principles and analysis. Brain 1998;121:1869-1887.
22 Li YJ, Scott WK, Hedges DJ, Zhang F, Gaskell PC, Nance MA, Watts RL, Hubble JP, Koller WC, Pahwa R, Stern MB, Hiner BC, Jankovic J, Allen FA Jr, Goetz CG, Mastaglia F, Stajich JM, Gibson RA, Middleton LT, Saunders AM, Scott BL, Small GW, Nicodemus KK, Reed AD, Schmechel DE, Welsh-Bohmer KA, Conneally PM, Roses AD, Gilbert JR, Vance JM, Haines JL, Pericak-Vance MA: Age at onset in two common neurodegenerative diseases is genetically controlled. Am J Hum Genet 2002; 7 : 985-993.

23 Bertram L, Blacker D, Mullin K, Keeney D, Jones J, Basu S, Yhu S, McInnis MG, Go RC, Vekrellis K, Selkoe DJ, Saunders AJ, Tanzi RE: Evidence for genetic linkage of Alzheimer's disease to chromosome 10q. Science 2000;290:2302-2303.

24 Blacker D, Bertram L, Saunders AJ, Moscarillo TJ, Albert MS, Wiener H, Perry RT, Collins JS, Harrell LE, Go RC, Mahoney A, Beaty T, Fallin MD, Avramopoulos D, Chase GA, Folstein MF, McInnis MG, Bassett SS, Doheny KJ, Pugh EW, Tanzi RE; NIMH Genetics Initiative Alzheimer's Disease Study Group: Results of a high-resolution genome screen of $437 \mathrm{Alz}$ heimer's disease families. Hum Mol Genet 2003; 12:23-32.

25 Farrer LA, Bowirrat A, Friedland RP, Waraska $\mathrm{K}$, Korczyn AD, Baldwin CT: Identification of multiple loci for Alzheimer disease in a consanguineous Israeli-Arab community. Hum Mol Genet 2003;12:415-422. 